\title{
Carcinogenic effects of bisphenol $A$ in breast and ovarian cancers (Review)
}

\author{
MIHAI CRISTIAN DUMITRASCU ${ }^{1,2^{*}}$, CRISTIAN MARES ${ }^{3 *}$, RAZVAN-COSMIN PETCA $^{3,4}$, \\ FLORICA SANDRU ${ }^{5,6}$, RAZVAN-IONUT POPESCU ${ }^{3}$, CLAUDIA MEHEDINTU $^{1,7}$ and AIDA PETCA ${ }^{1,8}$
}

\author{
${ }^{1}$ Department of Obstetrics and Gynecology, 'Carol Davila' University of Medicine and Pharmacy, 050474 Bucharest; \\ ${ }^{2}$ Department of Obstetrics and Gynecology, University Emergency Hospital, 050098 Bucharest; ${ }^{3}$ Department of Urology, \\ 'Prof. Dr. Th. Burghele' Clinical Hospital, 050659 Bucharest; ${ }^{4}$ Department of Urology, 'Carol Davila' University of Medicine \\ and Pharmacy, 050474 Bucharest; ${ }^{5}$ Department of Dermatology, Elias Emergency University Hospital, 011461 Bucharest; \\ ${ }^{6}$ Department of Dermatology, 'Carol Davila' University of Medicine and Pharmacy, 050474 Bucharest; \\ ${ }^{7}$ Department of Obstetrics and Gynecology, Malaxa Clinical Hospital, 022441 Bucharest; ${ }^{8}$ Department of \\ Obstetrics and Gynecology, Elias Emergency University Hospital, 011461 Bucharest, Romania
}

Received May 2, 2020; Accepted August 5, 2020

DOI: 10.3892/ol.2020.12145

\begin{abstract}
Endocrine-disrupting chemicals (EDCs) are exogenous chemical compounds ubiquitously found in everyday life of the modern world. EDCs enter the human body where they act similarly to endogenous hormones, altering the functions of the endocrine system and causing adverse effects on human health. Bisphenol A (BPA), the principal representative of this class, is a carbon-based synthetic plastic, and a key element in manufacturing cans, reusable water bottles and medical equipment. BPA mimics the actions of estrogen on multiple levels by activating estrogen receptors $\alpha$ and $\beta$. BPA regulates various processes, such as cell proliferation, migration and apoptosis, leading to neoplastic changes. Considering genetic mechanisms, BPA exerts its functions via multiple oncogenic signaling pathways, including the STAT3, PI3K/AKT and MAPK pathways. Furthermore, BPA is associated with various modifications of the reproductive system in both males and females. These alterations include benign lesions, such as endometrial hyperplasia, the development of ovarian cysts, an increase in the ductal density of mammary gland cells and other preneoplastic lesions. These benign lesions may continue to develop to breast or ovarian cancer; the effects of BPA depend on various molecular and epigenetic mechanisms that dictate whether the endocrine or
\end{abstract}

Correspondence to: Dr Razvan-Cosmin Petca, Department of Urology, 'Prof. Dr. Th. Burghele' Clinical Hospital, 20 Panduri Street, 050659 Bucharest, Romania

E-mail:drpetca@gmail.com

${ }^{*}$ Contributed equally

Key words: bisphenol A, ovarian cancer, breast cancer, endocrine-disrupting chemicals reproductive system is impacted, wherein preexisting benign lesions can become cancerous. The present review supports the need for continuous research on BPA, considering its widespread use and most available data suggesting a carcinogenic effect of BPA on the female reproductive system. Although most studies on BPA have been conducted in vitro with human cells or in vivo with animal models, it can be argued that more studies should be conducted in vivo with humans to further promote understanding of the impact of BPA.

\section{Contents}

1. Introduction

2. BPA: Everyday exposure

3. Key roles of BPA in the pathogenesis of multiple disorders

4. BPA: A key element in female cancers

5. Conclusions

\section{Introduction}

The use of plastic dates back to the 16th century, when men were shaping natural rubber with their hands and polymerizing it into objects of utility (1). Baekeland produced the first synthetic polymer in 1907 in Belgium (1). Plastics are polymers, which are chains of molecules with each chain composed of carbon, silicon, oxygen and/or hydrogen; and the process of linking chains together is termed polymerization. Combining plastic polymers with plasticizers, antioxidants, fillers, colorings or flame retardants, creates a variety of plastic materials with multiple properties. The risks for human health can be derived from the monomeric building block [such as bisphenol A (BPA)], the additives (such as plasticizers) or a combination of the two (such as antimicrobial polycarbonate) $(1,2)$.

Endocrine-disrupting chemicals (EDCs) represent ubiquitous natural or human-made plastic reagents that are absorbed 
by the human body and interfere with hormonal actions, resulting in disruptive effects at multiple levels of the endocrine system (3). Changes in the levels of the naturally present hormones circulating in the human body may be implicated in the rising incidence of numerous cancers of the reproductive system in both males and females (4). Disturbances in estrogen functions are associated with the occurrence of multiple preneoplastic or neoplastic lesions in females, such as breast, ovarian, endometrial or cervical cancer, which are considered to be highly responsive to changes in hormone levels (4).

BPA, or 4,40-dihydroxy-2,2-diphenylpropane, is an organic synthetic plastic monomer that was first synthesized in the 1890 s as a synthetic estrogen. However, the effects of this compound on the reproductive system of rats were only first reported in the 1930s (5); and later studies demonstrated on mice the induction of oxidative stress, DNA damage and epigenetic changes in oocytes (6). The 1940s industry was using BPA to make polymers, such as epoxy resins or polycarbonate, as a flame retardant, an antioxidant, or an inhibitor of polyvinyl chloride polymerization (7). In current practice, BPA is successfully used in manufacturing various consumer products, such as baby bottles, reusable plastic bottles, internal can coatings, dental materials and different medical devices (7). In Italy, in 2002, 0.25-1.2 mg/kg BPA, derived from plastic pipes, was found in drinking water (8). Various studies have suggested that it is likely $>90 \%$ of human exposure to BPA is due to food contamination, and the remaining exposure is due to dust ingestion, dermal absorption or dental surgeries $(8,9)$.

Considering the increasing prevalence of various health problems associated with exposure to BPA, with the majority leading to cancer or other significant issues, there is an imperative need for the present review. The latest studies in this field were searched to determine if current evidence is conclusive or if more extensive studies are required to demonstrate the impact of BPA on individuals and society as a significant public health problem.

\section{BPA: Everyday exposure}

BPA is an omnipresent chemical compound in everyday life of the modern world. Humans can be exposed to this chemical compound via various routes, such as oral, transdermal or inhalation. Food packaging, dental materials, thermal paper, toys, healthcare equipment, bottles for infants or children, and even dust represent significant sources of BPA contamination $(8,10)$. The most notable source of exposure to BPA is food (9), of which canned food and drinks represent considerable sources $(9,11,12)$. In addition, BPA is present in fresh food, such as eggs, milk, vegetables and fruits, due to the watering of soil with polluted water (11); and there are considerable traces of BPA in cardboard boxes that store food (12). The food industry relies heavily on BPA in manufacturing food cans; it is a key element in food preservation as it is used to coat the inside of cans, thus preventing direct contact of the food with metal, and it also determines the structural strength of the can and thermal stability (13). Dust from laminated floors, electronic equipment, epoxy resins and adhesives, and paint can also contain BPA (14). Exposure of infants or children to dust from various materials used for building or to everyday items they interact with, such as baby bottles, plastic drinking bottles, eyeglass wear, toys or bicycle helmets, have been demonstrated to be higher compared with other age categories $(15,16)$. It has been demonstrated by previous studies that BPA blood levels in children are higher compared with adults $(17,18)$.

The dental industry also represents a significant source of BPA exposure via dental fillings or other key materials used in the manufacturing of dental crowns (19); bisphenol A-glycidyl methacrylate (bis-GMA) is a primary compound used in this industry that may break down or be contaminated with BPA. Vast amounts of bis-GMA have been found in the saliva of patients following a dental visit (20).

\section{Key roles of BPA in the pathogenesis of multiple disorders}

To the best of our knowledge, only a limited number of studies on humans have investigated the association between BPA exposure during either intrauterine life or the postnatal period and its effects on general health. BPA has been associated with multiple metabolic disorders, such as polycystic ovarian syndrome, recurrent miscarriages and endometrial hyperplasia, as well as obesity and general health disorders, such as an altered immune system, cardiovascular disease, infertility, hormone-dependent tumors, diabetes in adults and precocious puberty (21-23). Women with polycystic ovarian syndrome (PCOS) present with higher circulating testosterone levels compared with healthy women. This particular group of female patients also exhibit higher circulting levels of serum BPA compared with women without PCOS, and it is understood that elevated levels of androgens decrease the clearance of BPA (24). Furthermore, women with endometriosis exhibit higher levels of serum BPA, suggesting an association between this chemical compound and the disease (25). A previous study indicated that patients with high urine levels of BPA have a higher chance of implantation failure during in vitro fertilization treatments (22). Nevertheless, exposure to BPA at an early age may be associated with multiple metabolic disorders. Associations of BPA exposure with adiposity, an increased body-fat percentage, a high body mass index and abdominal circumference, and numerous neurological implications, such as anxious or depressive behavior, has been observed in this category of young patients with the age ranging from 8 to 14 years $(23,26)$.

Extensive research over the last decade has demonstrated a close association between BPA exposure and the incidence of different neoplasias, particularly breast and ovarian cancers, and also likely prostate cancer, although this has not been completely concluded $(27,28)$. Either natural or anabolic steroids are acknowledged to be involved in the occurrence of these neoplasias (27-30).

\section{BPA: A key element in female cancers}

$B P A$ in ovarian cancer and other benign ovarian lesions. It has been demonstrated that exposure to $25-250 \mathrm{ng} / \mathrm{kg}$ BPA per day in the prenatal period in rats can induce changes in the gross ovarian anatomy (31). It is well documented that exposure to BPA in the prenatal period is associated with cystic endometrial hyperplasia, ovarian cysts, and a reduction in the primordial pool of follicles in mouse ovaries, indicating an association between BPA and increased proliferation of 
ovarian cells mediated by the estrogenic pathway $(31,32)$. Studies have shown an increase in the percentage of ovarian tissue that is occupied by antral follicles and also a decreased percentage of corpora lutea in rats groups treated with BPA for 3 months compared with controls, which is suggestive of a reduced number of oocytes $(31,32)$. Prenatal exposure to BPA can also result in a notable increase of unilateral or bilateral ovarian bursae filled with blood, which is a sign of reproductive ageing in 6-month-old mice (33). Furthermore, other studies have suggested that following accidental exposure to BPA, there is an increase in meiotic disturbances in mice, such as aneuploidy in oocytes $(34,35)$.

Ovarian cancer was reported in 2018 to be the seventh leading cause of cancer-associated mortality worldwide, and its 5-year survival rate is $<20 \%$ in women (36). Several studies have suggested an association between exposure to BPA and ovarian malignancy, as BPA mimics the effects of estrogen $(37,38)$. In addition, human ovarian cancer cells express elevated levels of estrogen receptors (ERs) compared with normal or benign ovarian lesion cells (36). Long-term exposure to BPA could lead to an increased incidence of cystic endometrial hyperplasia or ovarian cysts, which are premalignant lesions $(39,40)$. In both normal and malignant ovarian cells, there are two isoforms of ERs, $\mathrm{ER} \alpha$ and $\mathrm{ER} \beta$, and $\mathrm{ER} \beta$ expression in both normal and benign lesion cells is higher compared with ER $\alpha$ (41-43). The expression of ER $\alpha$ is higher in malignant tumors cells (44). ER $\alpha$ acts as an oncogene, while ER $\beta$ acts like a tumor suppressor. In normal cells, the expression of $\mathrm{ER} \beta$ is significantly higher compared with ER $\alpha$, but in ovarian tumoral cells the expression of $\mathrm{ER} \alpha$ is $40-60 \%$ higher than ER $\beta$ (44). ER $\alpha$ expression is higher in malignant cells compared with normal cells, while ER $\beta$ expression is higher in normal cells compared with malignant cells (44). Multiple studies have shown that $\operatorname{ER} \beta$ is considered to offer a protective role against cancer by promoting inhibition of cell migration and proliferation, or by inducing apoptosis $(36,45)$. Increased levels of both ER isoforms can be found in ovarian cancer compared with normal non-neoplastic ovaries, and the expression of this receptor is associated with unfavorable progression (46). Studies have reported that estrogens are capable of activating the proliferation of surface epithelial cells of ovaries and also mediating growth response and gene expression to produce changes in cancer cells $(47,48)$. In addition, it is understood that in postmenopausal women, estrogens can induce an increasing incidence of ovarian cancer $(49,50)$. Furthermore, multiple studies on animal models suggest that continuous exposure to BPA from the early stages of life can lead to a higher prevalence of alterations in the estrous cycle. Thus, BPA induces changes in ovarian morphology and ovulation, but also an increased incidence of endometriosis, cystic endometrial hyperplasia, proliferation lesions of the oviduct, stromal polyps, atypical hyperplasia, leiomyomas or adenomyosis $(39,51)$.

Analysis via PCR has shown that mRNA is altered at different levels during the processes of ovarian tumorigenesis. Upregulated mRNAs, such as CDK4, cyclin D1, cyclin A, proliferating cell nuclear antigen, E2F transcription factor (E2F)3 and E2F1, are associated with the cell cycle and cell proliferation, while other downregulated mRNAs, such as p21, GADD45 and Weel-1, are also associated with cell proliferation; and all of these cell cycle genetically-programed mechanisms have been shown to be modified by exposure to BPA (52). Multiple studies have demonstrated that BPA plays an important role in ovarian cancer by inducing activation of cell signaling pathways, such as the MAPK/ERK and PI3K/AKT pathways (53). Prenatal exposure to BPA can lead to inhibition of the expression of apoptotic genes, such as CAD, FAS, RAIDD, FADD, BOK and caspase, and can induce the expression of pro-survival genes, such as Mcl-1 and Bcl-x1, and also the growth of ovarian cancer cells via the specific signaling axis ER-CXCL12-CXCR-4 (54,55).

Ovarian cancer is considered to be highly fatal as it is often diagnosed in terminal stages when intraperitoneal metastasis is present (56). Intraperitoneal metastasis is induced by a decrease of E-cadherin, which leads to a loss of cell adhesion (57). The switch from E-cadherin to $\mathrm{N}$-cadherin expression is a key element in the dynamics of neoplastic cells (57). N-cadherin can induce the overexpression of matrix metalloproteinases (MMPs), which alters the extracellular matrix and the basal membrane, therefore promoting tumor invasion (57). MMP-9 and MMP-2 differ from other types of MMPs due to their ability to degrade type IV collagen $(58,59)$. It has been demonstrated that BPA stimulates granulosa lutein cells so that they express MMP-9, and elevated levels of MMP-9 and MMP-2 are associated with the metaplastic transformation of normal ovarian cells (39,60-62).

Not only BPA is associated with the occurrence of ovarian cancer; other EDCs, such as methoxychlor [1,1,1-trichlor-2,2-bis-(4-methoxyphenyl)ethane; MXC] and triclosan (TCS) act synergistically. These chemical compounds are ubiquitous in everyday products, such as toothpaste, deodorants and hygiene products (23). Recent studies have shown these two compounds at relatively low doses can induce the growth of BG-1 ovarian cancer cells by regulating p21, cyclin D1 and Bax genes, which are associated with the cell cycle and apoptosis $(62,63)$. In experimental models, BG-1 cells treated with TCS or MXC resulted in cyclin D1 upregulation, p21 downregulation and activation of Bax gene transcription. In addition, the ER antagonist ICI 182,780 can reverse the MXC and TSC-induced alterations of these particular genes, which suggests that the actions of these compounds are mediated by signaling pathways that are ER-dependent (63).

$B P A$ in breast cancer. Although endogenous estrogen has a higher potency compared with xenoestrogen, the latter is ubiquitous in nature and is more dangerous due to its resistance to enzymatic or chemical degradation (64).

Breast cancer is considered to be the most prevalent cancer type in female patients, and the main risk factors are due to genetic, lifestyle or environmental influences (65). EDCs are considered to contribute to the increasing incidence of breast cancer, particularly in critical periods of breast development, when mammary gland cells are the most predisposed to atypical differentiation (66-68). In vitro studies have demonstrated that exposure of human mammary gland cancer cells to BPA increases proliferation and oxidative stress, even at low doses (demonstrated for $10^{-10} \mathrm{M}$ ) for long-period exposure, of minimum 60 days $(69,70)$.

In immunohistochemical analysis of animal model, mammary gland tumors are investigated for the presence 
or the absence of three key receptors. In experimets with animal models, the long term effect of BPA was observed in gestational monkeys, demonstrating a significant increase in the density of mammary buds, and also an overall increase in the volume of mammary epithelium in newborns (71). A study on rats revealed that exposure during intrauterine life to different doses of BPA $(2.5,25,250$ and $1,000 \mu \mathrm{g} / \mathrm{kg} /$ day $)$ can lead to an exponential increase in the number of hyperplastic ducts at postnatal day 50 in a dose-independent manner and also a significant increase in these numbers even at a low dose at postnatal day 90 (72). Another study on rats demonstrated that the incidence of mammary tumors would increase following the administration of different doses of BPA $(0.25$, $2.5,25$ and $250 \mu \mathrm{g} / \mathrm{kg} /$ day) during both the gestational and lactation periods. Preneoplastic lesions were already observed at day 50. Atypical ductal hyperplasia or neoplastic modifications, like ductal carcinomas in situ, in mammary gland cells were diagnosed in the rats exposed to BPA. At postnatal day 200, malignant tumors were observed in female rats exposed to a low BPA dose of only $0.25 \mu \mathrm{g} / \mathrm{kg} / \mathrm{day}$, which were histopathologically diagnosed as benign fibroadenoma or adenocarcinomas. These findings demonstrate a direct association between BPA and breast cancer (73).

$\mathrm{ER} \alpha$ and $\mathrm{ER} \beta$ are expressed in greater than $60 \%$ of human breast cancers and are ligand-regulated transcription factors that control breast cancer proliferation $(74,75)$. Multiple studies have suggested that progesterone and estradiol are key factors in the malignant transformation of mammary gland cells, by increasing division and proliferation of cells in both mature and immature human breast tissue (74,75). It has been demonstrated that the therapy of estrogen replacement in postmenopausal women leads to an increased proliferation of terminal duct lobular units that represent the target site of breast cancer $(74,75)$. Additionally, breast cell proliferation increases in adulthood, when levels of progesterone and estradiol are higher. Estradiol determines the proliferation of mammary cells, which are positive for ER $\alpha$ expression. This effect is determined indirectly by growth factors, which are produced as a response to estrogenic regulation or directly by promoting the transcription of genes involved in the cell cycle, such as c-Myc (76). Furthermore, ERs are known to determine non-genomic signaling events in the extra-nuclear site of mammary cancer cells, which stimulate anti-apoptotic and proliferative signaling pathways as a response to growth factors or ligand binding. This non-genomic action is associated with the rapid response by activating estradiol pathways, which involves the action of MAPK, Src, PI3K, protein kinase-C and heterotrimeric G-proteins in the membrane or cytoplasm of target cells (77). Some biological effects, including cell growth, DNA synthesis, cell death and cell cycle progression, and also processes that are associated with ER cytoplasm re-localization, are attributed to activation by estradiol stimulation (78).

BPA functions as an xenoestrogen, and a number of studies with animal models have shown that it has important implications in breast cancer $(79,80)$. Results from animals studies have been used to predict what may occur in the human body, which lead to finding that the greater risk of breast cancer is associated with mutations of the susceptibility genes BRCA1 and BRCA2 in mammary gland cancer cells. These two genes are considered to act as tumor suppressor genes, resulting in hereditary ovarian or breast cancer syndrome (HBOC) if they undergo mutations in the germline, which is inherited in an autosomal-dominant manner. Individuals that present $\mathrm{HBOC}$ syndrome also have a higher risk of developing prostate cancer (8.6\% for BRCA1 mutations and $20 \%$ for BRCA2 mutations), pancreatic cancer (1-3\% for BRCA1 mutations and $2-7 \%$ for BRCA2 mutations) and melanoma (81). The incidence of HBOC syndrome accounts for approximately $6 \%$ of all breast cancer cases; however, the incidence of breast cancer accounts for greater than $70 \%$ of all HBOC cancer cases (79-83). Previous studies have demonstrated that women that exhibit mutations in BRCA1 and BRCA2 have a higher susceptibility to the negative effects of exposure to environmental BPA $(79,80,82)$. Furthermore, other studies have reported that the effects of BPA on adult breast tissue, both normal or cancerous, are associated with cell proliferation, the induction of chemoresistance in ER-positive cells and also the increase of mammosphere size $(82,83)$.

BPA acts through activating vascular endothelial growth factor, which is associated with angiogenesis in breast tumor, activation of the MAPK signaling pathway, STAT3 signaling, DNA repair, and changes in genes associated with apoptosis by DNA methylation (84-87). The expression of the long non-coding RNA HOX transcript antisense RNA, a key player in different neoplasias, including breast and ovarian cancer, inactivation of p53, and cell death or modulation of proliferation kinetics in human breast epithelial cells are also stimulated by BPA (84-87). These studies on the effects of BPA in humans suggest that BPA can play an important role in breast epithelial cells and carcinogenesis.

Considering the carcinogenic effect of different plastics on the human body, BPA is not the only EDC with important effects on health. Studies suggest other polychlorinated biphenyls, such as PCB-153 at a relatively high concentration $(35 \mu \mathrm{M})$, are associated with cell proliferation by regulating ERK1/2 activation (86-88). Furthermore, multiple studies suggest that organochlorine insecticides, such as p,p'-DDT (dichloro-diphenyl-tri-chloroethane) (DDT), p,p'-DDE and chlordane, are risk factors for breast cancer $(87,88)$. It has been suggested that DDT can lead to cancer progression by interfering with androgen signaling pathways and promoting the proliferation of breast cancer cells (88). Notably, it has been reported that in patients with breast cancer, exposure to DDT has negative effects on overall survival (88). Most available data in the literature suggest that organochlorine compounds influence the progression and pathogenesis of breast cancer.

\section{Conclusions}

EDCs are natural or synthetic chemical compounds that interact with the human endocrine system and are associated with various hormone-related diseases (89). BPA is the most widespread chemical compound among all EDCs, and substantial evidence indicates that BPA plays a negative role in various female reproductive system disorders and should be the subject of extensive research (90). BPA carries out effects via multiple mechanisms, most of which involve BPA binding to ERs and interfering with nuclear receptors (91), leading 
to an alteration in metabolism, the action of hormones or by inducing epigenetic dysregulation (92). Xenoestrogens mimic the effects of estrogen in humans, hence the name (93). BPA, the most widespread EDC in the modern world, can induce benign modifications in human ovaries, such as the progressive proliferation of the oviducts, endometriosis, cystic endometrial hyperplasia or ovarian cysts (94). Furthermore, evidence has suggested that BPA is implicated in the occurrence of ovarian cancer (95).

Moreover, in vivo studies with human cells and in vivo studies with animal models have demonstrated a direct association between exposure to environmental doses of BPA and a high incidence of breast cancer (96). In summary, research on the carcinogenic effects of BPA is a subject of lengthy debate, deciding on dose and the time-line between exposure and neoplasia, although most available data suggest it is associated with an increased risk of cancer incidence (97). Considering that most studies are conducted either in vitro on human cells or in vivo on animal models, it would be necessary to determine the effects of BPA through in vivo analyses, on humans domestic or job-related exposed for a definitive and improved understanding of its mechanisms of action. For example, determining serum BPA levels in individuals highly exposed would be important. Afterwards, in case of increased concentrations, measuring the mRNA expression of uridine diphosphate-glucuronosyl transferase, a resultant enzyme reaction product of BPA glucuronidation in the liver, would be necessary (98).

\section{Acknowledgements}

Not applicable.

\section{Funding}

No funding was received.

\section{Availability of data and materials}

Not applicable.

\section{Authors' contributions}

MCD, RCP and AP substantially contributed to the conception of the work, designed the review, and revised and edited the final manuscript. CMa, FS, RIP and CMe researched the literature and drafted the manuscript. All authors read and approved the final manuscript.

\section{Ethics approval and consent to participate}

Not applicable.

\section{Patient consent for publication}

Not applicable.

\section{Competing interests}

The authors declare that they have no competing interests.

\section{References}

1. Thompson RC, Swan SH, Moore CJ and vom Saal FS: Our plastic age. Philos Trans R Soc Lond B Biol Sci 364: 1973-1976, 2009.

2. Halden RU: Plastics and health risks. Annu Rev Public Health 31: 179-194, 2010.

3. Gore AC, Chappell VA, Fenton SE, Flaws JA, Nadal A, Prins GS, Toppari J and Zoeller RT: Executive summary to EDC-2: The endocrine society's second scientific statement on endocrine-disrupting chemicals. Endocr Rev 36: 593-602, 2015.

4. Rodriguez C, Patel AV, Calle EE, Jacob EJ and Thun MJ: Estrogen replacement therapy and ovarian cancer mortality in a large prospective study of US women. JAMA 285: 1460-1465, 2001.

5. Dodds LW and Lawson W: Synthetic estrogenic agents without the phenanthrene nucleus. Nature 137: 996, 1937.

6. Ding ZM, Jiao XF, Wu D, Zhang JY, Chen F, Wang YS, Huang CJ, Zhang SX, Li X and Huo LJ: Bisphenol AF negatively affects oocyte maturation of mouse in vitro through increasing oxidative stress and DNA damage. Chem Biol Interact 278: 222-229, 2017.

7. Geens T, Goeyens L and Covaci A: Are potential sources for human exposure to bisphenol-A overlooked? Int J Hyg Environ Health 214: 339-347, 2011.

8. Vivacqua A, Recchia AG, Fasanella G, Gabriele S, Carpino A, Rago V, Di Gioia ML, Leggio A, Bonofiglio D, Liguori A, et al: The food contaminants bisphenol A and 4-nonylphenol act as agonists for estrogen receptor alpha in MCF7 breast cancer cells. Endocrine 22: 275-284, 2003.

9. Geens T, Aerts D, Berthot C, Bourguignon JP, Goeyens L, Lecomte P, Maghuin-Rogister G, Pironnet AM, Pussemier L, Scippo ML, et al: A review of dietary and non-dietary exposure to bisphenol-A. Food Chem Toxicol 50: 3725-3740, 2012.

10. Konieczna A, Rutkowska A and Rachoń D: Health risk of exposure to Bisphenol A (BPA). Rocz Panstw Zakl Hig 66: 5-11, 2015.

11. Van Landuyt KL, Nawrot T, Geebelen B, De Munck J, Snauwaert J, Yoshihara K, Scheers H, Godderis L, Hoet P and Van Meerbeek B: How much do resin-based dental materials release? A meta-analytical approach. Dent Mater 27: 723-747, 2011.

12. Oldring PK, Castle L, O'Mahony $\mathrm{C}$ and Dixon J: Estimates of dietary exposure to bisphenol A (BPA) from light metal packaging using food consumption and packaging usage data: A refined deterministic approach and a fully probabilistic (FACET) approach. Food Addit Contam Part A Chem Anal Control Expo Risk Assess 31: 466-489, 2014.

13. Cao XL, Corriveau J and Popovic S: Bisphenol a in canned food products from canadian markets. J Food Prot 73: 1085-1089, 2010.

14. Hanaoka T, Kawamura N, Hara K and Tsugane S: Urinary bisphenol A and plasma hormone concentrations in male workers exposed to bisphenol A diglycidyl ether and mixed organic solvents. Occup Environ Med 59: 625-628, 2002.

15. Calafat AM, YeX, Wong LY, Reidy JA and Needham LL: Exposure of the U.S. population to bisphenol A and 4-tertiary-octylphenol: 2003-2004. Environ Health Perspect 116: 39-44, 2008.

16. Erler $\mathrm{C}$ and Novak J: Bisphenol a exposure: Human risk and health policy. J Pediatr Nurs 25: 400-407, 2010.

17. Zhang T, Sun H and Kannan K: Blood and urinary bisphenol A concentrations in children, adults, and pregnant women from china: Partitioning between blood and urine and maternal and fetal cord blood. Environ Sci Technol 47: 4686-4694, 2013.

18. Huang RP, Liu ZH, Yin H, Dang Z, Wu PX, Zhu NW and Lin Z: Bisphenol A concentrations in human urine, human intakes across six continents, and annual trends of average intakes in adult and child populations worldwide: A thorough literature review. Sci Total Environ 626: 971-981, 2018.

19. Drozdz K, Wysokinski D, Krupa R and Wozniak K: Bisphenol A-glycidyl methacrylate induces a broad spectrum of DNA damage in human lymphocytes. Arch Toxicol 85: 1453-1461, 2011

20. Fleisch AF, Sheffield PE, Chinn C, Edelstein BL and Landrigan PJ: Bisphenol A and related compounds in dental materials. Pediatrics 126: 760-768, 2010.

21. Dumitrascu MC, Iliescu M, Petca RC, Sandru F, Mehedintu C, Farcasanu PD, Maru N, Chibelean C and Petca A: The chemical pregnancy. Rev Chim 70: 3818-3823, 2019.

22. Ehrlich S, Williams PL, Missmer SA, Flaws JA, YeX, Calafat AM, Petrozza JC, Wright D and Hauser R: Urinary bisphenol A concentrations and early reproductive health outcomes among women undergoing IVF. Hum Reprod 27: 3583-3592, 2012. 
23. Petca A, Bot M, Petca RC, Mehedintu C, Barac RI, Iliescu M, Maru N and Mastalier B: Chemicals in personal care tied to early puberty in girls. Rev Chim 70: 3206-3209, 2019.

24. Fernández M, Bourguignon N, Lux-Lantos V and Libertun C: Neonatal exposure to bisphenol a and reproductive and endocrine alterations resembling the polycystic ovarian syndrome in adult rats. Environ Health Perspect 118: 1217-1222, 2010.

25. Cobellis L, Colacurci N, Trabucco E, Carpentiero C and Grumetto L: Measurement of bisphenol A and bisphenol B levels in human blood sera from healthy and endometriotic women. Biomed Chromatogr 23: 1186-1190, 2009.

26. Hoepner LA, Whyatt RM, Widen EM, Hassoun A, Oberfield SE Mueller NT, Diaz D, Calafat AM, Perera FP and Rundle AG: Bisphenol A and Adiposity in an Inner-City Birth Cohort. Environ Health Perspect 124: 1644-1650, 2016

27. Castoria G, Giovannelli P, Lombardi M, De Rosa C, Giraldi T, de Falco A, Barone MV, Abbondanza C, Migliaccio A and Auricchio F: Tyrosine phosphorylation of estradiol receptor by Src regulates its hormone-dependent nuclear export and cell cycle progression in breast cancer cells. Oncogene 31: 4868-4877, 2012.

28. Mares C, Popescu R, Petca A, Maru N, Dogaroiu C and Petca RC: Bisphenol-A and other plastics: Review of endocrine disrupting effects on prostate cancer. Mater Plast 57: 239-252, 2020.

29. Lombardi M, Castoria G, Migliaccio A, Barone MV, Di Stasio R, Ciociola A, Bottero D, Yamaguchi H, Appella E and Auricchio F: Hormone-dependent nuclear export of estradiol receptor and DNA synthesis in breast cancer cells. J Cell Biol 182: 327-340, 2008.

30. Varricchio L, Migliaccio A, Castoria G, Yamaguchi H, de Falco A, Di Domenico M, Giovannelli P, Farrar W, Appella E and Auricchio F: Inhibition of estradiol receptor/Src association and cell growth by an estradiol receptor alpha tyrosine-phosphorylated peptide. Mol Cancer Res 5: 1213-1221, 2007.

31. Rodríguez HA, Santambrosio N, Santamaría CG, Muñoz-de-Toro $M$ and Luque EH: Neonatal exposure to bisphenol A reduces the pool of primordial follicles in the rat ovary. Reprod Toxicol 30: 550-557, 2010.

32. Markey CM, Coombs MA, Sonnenschein C and Soto AM Mammalian development in a changing environment: Exposure to endocrine disruptors reveals the developmental plasticity of steroid-hormone target organs. Evol Dev 5: 67-75, 2003

33. Hunt PA, Koehler KE, Susiarjo M, Hodges CA, Ilagan A, Voigt RC, Thomas S, Thomas BF and Hassold TJ: Bisphenol a exposure causes meiotic aneuploidy in the female mouse. Curr Biol 13: 546-553, 2003

34. Mei L, Chen H, Wei DM, Fang F, Liu GJ, Xie HY, Wang X, Zou J, Han X and Feng D: Maintenance chemotherapy for ovarian cancer. Cochrane Database Syst Rev 9: CD007414, 2010.

35. Petca A, Petca RC, Zvanca M, Maru N, Mastalier B and Dogaroiu C: Fetal death from ruptured vasa previa: A tragic event in the ultrasonographic era. Rom J Leg Med 27: 43-46, 2019.

36. Momenimovahed Z, Tiznobaik A, Taheri S and Salehiniya H: Ovarian cancer in the world: Epidemiology and risk factors. Int J Womens Health 11: 287-299, 2019.

37. Dekant W and Völkel W: Human exposure to bisphenol A by biomonitoring: Methods, results and assessment of environmental exposures. Toxicol Appl Pharmacol 228: 114-134, 2008.

38. Akahira J, Suzuki T, Ito K, Kaneko C, Darnel AD, Moriya T, Okamura K, Yaegashi N and Sasano H: Differential expression of progesterone receptor isoforms A and B in the normal ovary, and in benign, borderline, and malignant ovarian tumors. Jpn $J$ Cancer Res 93: 807-815, 2002.

39. Newbold RR, Jefferson WN and Padilla-Banks E: Long-term adverse effects of neonatal exposure to bisphenol $\mathrm{A}$ on the murine female reproductive tract. Reprod Toxicol 24: 253-258, 2007.

40. Enmark E, Pelto-Huikko M, Grandien K, Lagercrantz S, Lagercrantz J, Fried G, Nordenskjöld M and Gustafsson JA: Human estrogen receptor beta-gene structure, chromosomal localization, and expression pattern. J Clin Endocrinol Metab 82: 4258-4265, 1997.

41. Kuiper GG and Gustafsson JA: The novel estrogen receptor-beta subtype: Potential role in the cell- and promoter-specific actions of estrogens and anti-estrogens. FEBS Lett 410: 87-90, 1997.

42. Pujol P, Rey JM, Nirde P, Roger P, Gastaldi M, Laffargue F, Rochefort $\mathrm{H}$ and Maudelonde T: Differential expression of estrogen receptor- $\alpha$ and $-\beta$ messenger RNAs as a potential marker of ovarian carcinogenesis. Cancer Res 58: 5367-5373, 1998.
43. Bardin A, Hoffmann P, Boulle N, Katsaros D, Vignon F, Pujol P and Lazennec G: Involvement of estrogen receptor beta in ovarian carcinogenesis. Cancer Res 64: 5861-5869, 2004.

44. Hua H, Zhang H, Kong Q and Jiang Y: Mechanisms for estrogen receptor expression in human cancer. Exp Hematol Oncol 7: 24, 2018.

45. Münstedt K, Steen J, Knauf AG, Buch T, von Georgi R and Franke FE: Steroid hormone receptors and long term survival in invasive ovarian cancer. Cancer 89: 1783-1791, 2000.

46. Bai W, Oliveros-Saunders B, Wang Q, Acevedo-Duncan ME and Nicosia SV: Estrogen stimulation of ovarian surface epithelial cell proliferation. In Vitro Cell Dev Biol Anim 36: 657-666, 2000.

47. O'Donnell AJ, Macleod KG, Burns DJ, Smyth JF and Langdon SP: Estrogen receptor-alpha mediates gene expression changes and growth response in ovarian cancer cells exposed to estrogen. Endocr Relat Cancer 12: 851-866, 2005.

48. Riman T, Dickman PW, Nilsson S, Correia N, Nordlinder H, Magnusson CM, Weiderpass E and Persson IR: Hormone replacement therapy and the risk of invasive epithelial ovarian cancer in Swedish women. J Natl Cancer Inst 94: 497-504, 2002.

49. Lacey JV Jr, Mink PJ, Lubin JH, Sherman ME, Troisi R, Hartge P, Schatzkin A and Schairer C: Menopausal hormone replacement therapy and risk of ovarian cancer. JAMA 288: 334-341, 2002.

50. Suzuki A, Sugihara A, Uchida K, Sato T, Ohta Y, Katsu Y, Watanabe $\mathrm{H}$ and Iguchi T: Developmental effects of perinatal exposure to bisphenol-A and diethylstilbestrol on reproductive organs in female mice. Reprod Toxicol 16: 107-116, 2002.

51. Ptak A, Wróbel A and Gregoraszczuk EL: Effect of bisphenol-A on the expression of selected genes involved in cell cycle and apoptosis in the OVCAR-3 cell line. Toxicol Lett 202: 30-35, 2011.

52. Ptak A and Gregoraszczuk EL: Bisphenol A induces leptin receptor expression, creating more binding sites for leptin, and activates the JAK/Stat, MAPK/ERK and PI3K/Akt signalling pathways in human ovarian cancer cell. Toxicol Lett 210: 332-337, 2012.

53. Bredhult C, Bäcklin BM and Olovsson M: Effects of some endocrine disruptors on the proliferation and viability of human endometrial endothelial cells in vitro. Reprod Toxicol 23: 550-559, 2007.

54. Hall JM and Korach KS: Endocrine disrupting chemicals promote the growth of ovarian cancer cells via the ER-CXCL12-CXCR4 signaling axis. Mol Carcinog 52: 715-725, 2013.

55. Cavallaro $U$ and Christofori G: Multitasking in tumor progression: Signaling functions of cell adhesion molecules. Ann N Y Acad Sci 1014: 58-66, 2004.

56. Lengyel E: Ovarian cancer development and metastasis. Am J Pathol 177: 1053-1064, 2010.

57. Hazan RB, Phillips GR, Qiao RF, Norton L and Aaronson SA: Exogenous expression of $\mathrm{N}$-cadherin in breast cancer cells induces cell migration, invasion, and metastasis. J Cell Biol 148: 779-790, 2000.

58. Hudson LG, Zeineldin R and Stack MS: Phenotypic plasticity of neoplastic ovarian epithelium: Unique cadherin profiles in tumor progression. Clin Exp Metastasis 25: 643-655, 2008.

59. Davidson B, Goldberg I, Gotlieb WH, Kopolovic J, Ben-Baruch G, Nesland JM and Reich R: The prognostic value of metalloproteinases and angiogenic factors in ovarian carcinoma. Mol Cell Endocrinol 187: 39-45, 2002

60. Kenny HA and Lengyel E: MMP-2 functions as an early response protein in ovarian cancer metastasis. Cell Cycle 8: 683-688, 2009.

61. Symowicz J, Adley BP, Gleason KJ, Johnson JJ, Ghosh S, Fishman DA, Hudson LG and Stack MS: Engagement of collagen-binding integrins promotes matrix metalloproteinase-9-dependent E-cadherin ectodomain shedding in ovarian carcinoma cells. Cancer Res 67: 2030-2039, 2007.

62. Kim JY, Yi BR, Go RE, Hwang KA, Nam KH and Choi KC: Methoxychlor and triclosan stimulates ovarian cancer growth by regulating cell cycle- and apoptosis-related genes via an estrogen receptor-dependent pathway. Environ Toxicol Pharmacol 37: 1264-1274, 2014

63. Teilmann G, Juul A, Skakkebaek NE and Toppari J: Putative effects of endocrine disrupters on pubertal development in the human. Best Pract Res Clin Endocrinol Metab 16: 105-121, 2002.

64. Fenichel P, Chevalier N and Brucker-Davis F: Bisphenol A: An endocrine and metabolic disruptor. Ann Endocrinol (Paris) 74: 211-220, 2013. 
65. Chibelean CB, Petca RC, Radu DC and Petca A: State of the art in fertility preservation for female patients prior to oncologic therapies. Medicina (Kaunas) 56: 89, 2020.

66. Tsuda H, Naito A, Kim CK, Fukamachi K, Nomoto H and Moore MA: Carcinogenesis and its modification by environmental endocrine disruptors: In vivo experimental and epidemiological findings. Jpn J Clin Oncol 33: 259-270, 2003.

67. Fenton SE: Endocrine-disrupting compounds and mammary gland development: Early exposure and later life consequences. Endocrinology 147 (Suppl): S18-S24, 2006.

68. Fernandez SV and Russo J: Estrogen and xenoestrogens in breast cancer. Toxicol Pathol 38: 110-122, 2010.

69. Wetherill YB, Akingbemi BT, Kanno J, McLachlan JA, Nadal A, Sonnenschein C, Watson CS, Zoeller RT and Belcher SM: In vitro molecular mechanisms of bisphenol A action. Reprod Toxicol 24: 178-198, 2007.

70. Tharp AP, Maffini MV, Hunt PA, VandeVoort CA Sonnenschein $\mathrm{C}$ and Soto AM: Bisphenol A alters the development of the rhesus monkey mammary gland. Proc Natl Acad Sci USA 109: 8190-8195, 2012

71. Murray TJ, Maffini MV, Ucci AA, Sonnenschein C and Soto AM: Induction of mammary gland ductal hyperplasias and carcinoma in situ following fetal bisphenol A exposure. Reprod Toxicol 23 : 383-390, 2007.

72. Acevedo N, Davis B, Schaeberle CM, Sonnenschein C and Soto AM: Perinatally administered bisphenol a as a potential mammary gland carcinogen in rats. Environ Health Perspect 121: 1040-1046, 2013.

73. Hofseth LJ, Raafat AM, Osuch JR, Pathak DR, Slomski CA and Haslam SZ: Hormone replacement therapy with estrogen or estrogen plus medroxyprogesterone acetate is associated with increased epithelial proliferation in the normal postmenopausal breast. J Clin Endocrinol Metab 84: 4559-4565, 1999.

74. Santen RJ and Harvey HA: Use of aromatase inhibitors in breast carcinoma. Endocr Relat Cancer 6: 75-92, 1999.

75. Zgura A, Gales L, Haineala B, Bratila E, Mehedintu C, Andreescu CV, Berceanu C, Petca A, Barac RI, Ionescu A, et al: Correlations between known prognostic markers and tumor - infiltrating lymphocytes in breast cancer. Rev Chim 70 : 2362-2366, 2019

76. Migliaccio A, Castoria G and Auricchio F: Src-dependent signalling pathway regulation by sex-steroid hormones: Therapeutic implications. Int J Biochem Cell Biol 39: 1343-1348, 2007.

77. Castoria G, Migliaccio A, Di Domenico M, Lombardi M, de Falco A, Varricchio L, Bilancio A, Barone MV and Auricchio F. Role of atypical protein kinase $C$ in estradiol-triggered G1/S progression of MCF-7 cells. Mol Cell Biol 24: 7643-7653, 2004.

78. Foulkes WD: Inherited susceptibility to common cancers. N Engl J Med 359: 2143-2153, 2008.

79. Fernandez SV, Huang Y, Snider KE, Zhou Y, Pogash TJ and Russo J: Expression and DNA methylation changes in human breast epithelial cells after bisphenol A exposure. Int J Oncol 41 : 369-377, 2012

80. Jung JW, Park SB, Lee SJ, Seo MS, Trosko JE and Kang KS Metformin represses self-renewal of the human breast carcinoma stem cells via inhibition of estrogen receptor-mediated OCT4 expression. PLoS One 6: e28068, 2011.

81. Rathore A, Ranjan S and Dubey AP: Hereditary breast-ovarian cancer syndrome. Cancer Res Stat Treat 3: 374-375, 2020.
82. Lapensee EW, Tuttle TR, Fox SR and Ben-Jonathan N: Bisphenol A at low nanomolar doses confers chemoresistance in estrogen receptor-alpha-positive and -negative breast cancer cells. Environ Health Perspect 117: 175-180, 2009.

83. Dairkee SH,Luciani-Torres MG,Moore DH and Goodson WH III Bisphenol-A-induced inactivation of the p53 axis underlying deregulation of proliferation kinetics, and cell death in non-malignant human breast epithelial cells. Carcinogenesis 34 : 703-712, 2013

84. Zhang W, Fang Y, Shi X, Zhang M, Wang X and Tan Y: Effect of bisphenol A on the EGFR-STAT3 pathway in MCF-7 breast cancer cells. Mol Med Rep 5: 41-47, 2012.

85. Buteau-Lozano H, Velasco G, Cristofari M, Balaguer P and Perrot-Applanat M: Xenoestrogens modulate vascular endothelial growth factor secretion in breast cancer cells through an estrogen receptor-dependent mechanism. J Endocrinol 196: 399-412, 2008

86. Dong S, Terasaka S and Kiyama R: Bisphenol A induces a rapid activation of Erk1/2 through GPR30 in human breast cancer cells. Environ Pollut 159: 212-218, 2011

87. Radice S, Chiesara E, Fucile S and Marabini L: Different effects of PCB101, PCB118, PCB138 and PCB153 alone or mixed in MCF-7 breast cancer cells. Food Chem Toxicol 46: 2561-2567, 2008.

88. Parada H Jr, Wolff MS, Engel LS, Eng SM, Khankari NK, Neugut AI, Teitelbaum SL and Gammon MD: Polychlorinated biphenyls and their association with survival following breast cancer. Eur J Cancer 56: 21-30, 2016.

89. Combarnous Y and Nguyen TMD: Comparative overview of the mechanisms of action of hormones and endocrine disruptor compounds. Toxics 7: 5, 2019.

90. Nagel SC and Bromfield JJ: Bisphenol a: A model endocrine disrupting chemical with a new potential mechanism of action. Endocrinology 154: 1962-1964, 2013.

91. Li L, Wang Q, Zhang Y, Niu Y, Yao X and Liu H: The molecular mechanism of bisphenol A (BPA) as an endocrine disruptor by interacting with nuclear receptors: Insights from molecular dynamics (MD) simulations. PLoS One 10: e0120330, 2015.

92. Acconcia F, Pallottini V and Marino M: Molecular mechanisms of action of BPA. Dose Response 13: 1559325815610582, 2015.

93. Paterni I, Granchi C and Minutolo F: Risks and benefits related to alimentary exposure to xenoestrogens. Crit Rev Food Sci Nutr 57: 3384-3404, 2017.

94. Caserta D, Di Segni N, Mallozzi M, Giovanale V, Mantovani A, Marci R and Moscarini M: Bisphenol A and the female reproductive tract: An overview of recent laboratory evidence and epidemiological studies. Reprod Biol Endocrinol 12: 37, 2014.

95. Hui L, Li H, Lu G, Chen Z, Sun W, Shi Y, Fu Z, Huang B, Zhu X, $\mathrm{Lu} \mathrm{W}$, et al: Low dose of bisphenol a modulates ovarian cancer gene expression profile and promotes epithelial to mesenchymal transition via canonical wnt pathway. Toxicol Sci 164: 527-538, 2018.

96. Weber Lozada K and Keri RA: Bisphenol A increases mammary cancer risk in two distinct mouse models of breast cancer. Biol Reprod 85: 490-497, 2011.

97. Seachrist DD, Bonk KW, Ho SM, Prins GS, Soto AM and Keri RA: A review of the carcinogenic potential of bisphenol A. Reprod Toxicol 59: 167-182, 2016.

98. Caporossi L and Papaleo B: Exposure to Bisphenol A and gender differences: From rodents to humans evidences and hypothesis about the health effects. J Xenobiot 5: 5264, 2015. 